\title{
Covid-19 Infected Patient's Service Rights Get Health Services from Hospitals
}

\author{
Wildan Sani ${ }^{1}$, Faisal Santiago ${ }^{2}$ \\ Universitas Borobudur ${ }^{1,2}$ \\ \{wildanunbor@gmail.com¹, faisalsantiago@borobudur.ac.id²
}

\begin{abstract}
There is recognition of national law and international law on the right to health so that every citizen who has a health complaint is entitled to health services from the hospital. This paper uses a normative legal approach that looks at the law on a natural basis with qualitative data support. This study aims to review the right of health services to patients infected with Covid-19 in Indonesia. This study's result is the number of patients infected with coronavirus who do not get wards in hospitals, so they have to get self-isolation services in other locations. This study concludes that the Government of Indonesia is not ready for a pandemic, so it is necessary to make policies that can cope with pandemic conditions.
\end{abstract}

Keywords: Health Rights; Covid-19 patients; health care; Hospitals

\section{Introduction}

Covid 19 or what we often know as the corona virus is a virus that started with pneumonia or mysterious hoarseness of the lungs in December 2019. This corona virus was first discovered in Wuhan and is associated with a forest animal market that sells various types of animals, including those can not be consumed, such as bats, and various types of mice. Many cases of the corona virus are found in these animal markets. This corona virus is thought to be carried by bats and other animals that are eaten by humans until transmission occurs. Coronavirus is no stranger to the world of animal health, but only a few types can infect humans and cause pneumonia.

Covid 19, which originated in the city of Wuhan, China, was discovered at the end of December 2019. This virus causes diseases of the respiratory tract. This corona virus spreads rapidly to humans. on March 12, 2020 the World Health Organization (WHO) determined that the phenomenon of the spread of covid 19 was a pandemic. A pandemic is a condition that spreads certain types of diseases that occur throughout the country. The spread of the corona virus disease is uncontrolled, causing this spread very quickly to almost all parts of the world. This cause exceeds an epidemic cotton which makes the status of the spread of Covid 19 has become a pandemic outbreak.

Based on the very fast spread of the virus and many people who are affected by the corona virus, it requires fast handling. The high need for subscribing to the corona virus makes the high number of health workers needed in handling this virus. The large number of people 
infected with the corona virus has made many hospitals accommodating people affected by the corona virus.

Indonesia is one of the countries affected by the corona virus pandemic. Cases of spread every day are increasing and health medical personnel who play a role at the forefront of the field are also potential to be vulnerable to being infected with Covid 19 because of the low readiness in safety of the spread of the corona virus Many of the patients infected with the corona virus are quarantined or hospitalized. The increasing number of patients infected with the corona virus, the capacity of the hospital that does not reach and treat all infected patients, so some infected patients for independent isolation in their respective homes or other locations. The right of every patient to be treated at the hospital is questionable. Even before the Covid 19 pandemic we were free to visit relatives or families who were hospitalized but when the current pandemic occurred, we had to be careful and when going to the hospital we had to keep everything and could not be free, everything was limited to prevent transmission of the corona virus.

From the above explanation, the authors are interested in examining the rights of patients who are treated at the hospital who do not get a place to be hospitalized at the hospital, so they must be independently isolated in their respective homes or in other locations. A full hospital due to the large number of inpatients makes the inpatient place full. Not all hospitals provide special care for patients affected or infected with the Covid 19 virus.

\section{Problem Statement}

The formulation of the problem raised in this study is how to enforce the rights of patients infected with the corona virus who do not have a place to be hospitalized in a hospital so that they must isolate independently in their respective homes or certain locations?

\section{Research Methods}

The method in this writing uses a normative legal approach using a variety of secondary data such as statutory regulations, court decisions, legal theory, and the opinions of scholars. This research is supported by qualitative data which explains the existing data in words or statements not in numbers. This research is commonly called library research because it is only shown for written regulations so that it is closely related to libraries as a source of secondary data.

\section{Literature Review}

\subsection{Pandemi Virus Corona (Covid 19)}

A pandemic is a spread of certain types of disease that spreads very quickly to countries around the world. On January 30, 2020, the Director General of WHO declared the coronavirus disease (COVID 19) outbreak as a public health emergency that was troubling the world. In line with the development of this outbreak, noble member countries are considering options for preventing the emergence of disease in new areas or reducing human-to-human transmission where the Covid 19 virus has begun to spread.[1] 
The Covid 19 virus that has spread throughout the country has been declared a pandemic. On March 31, 2020, the President of the Republic of Indonesia Joko Widodo issued a decree of the President of the Republic of Indonesia Number 11 of 2020 concerning the Determination of Public Health Emergencies for Corona Virus Disease 2019 (Covid-19). "Defining Corona virus Disease 2019 (Covid-19) as a type of disease that causes a Public Health Emergency"

"Determining the Public Health Emergency for Corona Virus Disease 2019 (Covid-19) in Indonesia, which requires countermeasures in accordance with the provisions of laws and regulations."[2] This cannot be taken lightly and must pay serious attention to the survival of life together in the community. So every citizen must comply with applicable rules to prevent this transmission and control the problem of the corona virus outbreak. The government also issued a policy to establish health protocols that everyone must comply with for the sake of common health. Health protocols implemented by the government include wearing masks, not touching objects in public places carelessly, always maintaining distance, and maintaining cleanliness. The government also recommends that we stay at home. This recommendation is shown for people who feel unwell.

\subsection{Gejala Covid 19}

Symptoms of people infected with the corona virus have characteristics with early flu-like symptoms so that they are often underestimated by affected patients. However, unlike the common cold, infection with the corona virus or covid 19 runs very quickly, especially in patients with previous health problems. There are mild symptoms and also severe symptoms of a corona virus infection case (Covid 19). Mild symptoms of this infection include coughing, fatigue, shortness of breath and aches all over the body and a general feeling of unwell. Severe symptoms of people infected with the corona virus (Covid 19) include difficulty breathing, pneumonia infection, pain in the stomach, decreased appetite.

Symptoms of being infected with the corona virus (covid 19) mostly appear 2-10 days after the person comes in contact with the corona virus or comes into contact with a patient who has the corona virus. But in some cases, the initial features of the coronavirus and symptoms only appear for about 24 days. To distinguish the initial characteristics of the corona and the common cold, there are several things that must be considered, namely

a. Within 14 days I traveled to a country that is considered the source of the corona virus

b. Had contact with a patient who had a corona infection.

\subsection{Pencegahan Penularan Covid 19}

The spread of the corona virus (Covid-19) is very fast, so we must be able to prevent the spread of this virus outbreak with a simple one. Here's how to prevent the spread of the corona virus:

a. Wash hands. Wash your hands with soap and water for at least 20 seconds. If there is no water, you can use a hand sanitizer with an alcohol content of approximately 70 percent. Wash your hands should be done before and after activities.

b. Do not touch facilities carelessly in public places. When in a public place, you should not carelessly hold objects that are often held by other people. If you touch the hands or the parts that are touched, wash them immediately or use a hand sanitizer. 
c. Be diligent in cleaning the house. Having to be diligent in cleaning the house with this disinfectant is another effort to prevent cases of infection with the corona virus or covid 19

d. Avoid crowds. Cases of the spread of the corona virus are easy to attack when in crowded places. Therefore, try not to be in the crowd, especially in a room that has bad ventilation. If forced to be in a crowd, don't touch your face, nose, eyes and always wear a mask.

\subsection{Karantina}

There is a corona virus pandemic that has hit Indonesian society which has fatal consequences for health. This disease epidemic is very easy to spread. In accordance with the Law of the Republic of Indonesia No. 4 of 1984 what is meant by the Plague is "An epidemic of an infectious disease, hereinafter referred to as an epidemic, is an outbreak of an infectious disease in the community where the number of sufferers has increased significantly, exceeding the usual conditions at a certain time and in a certain area and can cause disaster"[3]

So the government recommends that everyone infected with the corona covid 19 virus must quarantine either in the hospital if there is still a place or independent isolation so that the spread of this virus does not spread and transmit to people who have never been infected. The government is making countermeasures to break the chain of the spread of the Covid 19 virus. In accordance with the government regulation of the Republic of Indonesia Number 40 of 1991 what is meant by efforts to overcome is "Countermeasures are all efforts shown to reduce the death rate, limit transmission and spread so that the epidemic does not spread to other areas."[4]

Person quarantine is the restriction of activities or segregation of people who are not sick, but may be exposed to infectious agents or infectious diseases, with the aim of monitoring symptoms and detecting cases early. Quarantine is different from isolation, which is the separation of sick or infected people from other people, thereby preventing the spread of infection or contamination.[1]

Prior to implementing quarantine, the State must properly communicate and socialize these measures to reduce levels of panic and increase compliance. The public must be provided with clear, current, transparent and consistent guidance, as well as convincing information on quarantine measures, by the authorities. People who are quarantined need to be provided with health, financial, social and psychological support, and basic necessities such as food, water and other basic necessities.

Taking into account Presidential Decree No.12 of 2020 stipulates that non-natural disasters the spread of corona virus disease 2019 (Covid 19) as a national disaster explains that the second: "The response to national disasters caused by the spread of Corona Virus Disease 2019 (Covid 19) is carried out by the task force to accelerate subscriptions to Corona Virus Disease 2019 (Covid 19) in accordance with Presidential Decree No.7 of 2020 concerning the Task Force for the Acceleration of Subscription to Corona Virus Disease 2019 (Covid 19) as amended by Presidential Decree Number 9 of 2020 concerning amendments to Presidential Decree Number 7 of 2020 concerning the Task Force for the Acceleration of Subscription to Corona Virus Disease 2019 (Covid 19) through synergy between ministries / institutions and the central government."[5]

\subsection{Rumah Sakit}


The Law of the Republic of Indonesia Number 44 of 2009 concerning the hospital explains what is meant by the hospital is "Hospital is a health service institution that provides complete individual health services that provide inpatient, outpatient, and emergency services."[6]

People infected with the corona virus are immediately taken to the hospital for examination. The hospital has the task of providing complete health services to individuals to every person who goes to the hospital. During this pandemic, the hospital played an important role in dealing with people who were exposed to this virus, but it is very unfortunate that not all hospitals can serve people exposed to the corona virus because of the limited equipment and facilities from the hospital itself. In carrying out its duties as referred to in Article 4, the hospital has the following functions:

a. Providing treatment and recovery services in accordance with hospital service standards;

b. Maintenance and improvement of individual health through complete second and third level health services according to medical needs;

c. Providing education and training for human resources in order to increase the capacity in providing health;

d. Carrying out research and development as well as screening technology in the health sector in order to improve health services by taking into account the ethics of health science.[6]

In carrying out the duties and functions of the hospital, it must pay attention to the health of the patients. Health is a human right and one of the elements of welfare that must be realized. In the Law of the Republic of Indonesia Number 36 of 2009 concerning health, it explains that what is meant by health is "Health is a state of health, both physically, mentally, spiritually and socially which allows everyone to live productively socially and economically."[7]

Health medical personnel at the hospital experienced a high number of increases due to the large number of patients exposed to or infected with the corona virus (Covid 19). The hospital added the number of medical personnel to overcome this. Health workers are people who devote themselves to the health sector and have knowledge and / or skills through education in the health sector which for certain jensi requires the authority to make health efforts. The role of health workers is very important during this corona virus pandemic.

\section{Analysis and Discussion}

Patients infected with the corona virus (Covid 19) have the same rights in hospital care. Patients who feel that they have symptoms such as Covid 19 should immediately consult the nearest hospital. If the results of the examination show that the person is identified as having positive COVID-19, the person must be immediately isolated in a hospital or other place. Every person who has the examination has the same right to be served by health workers who are in the hospital. If the hospital is full, the hospital will recommend the patient to another hospital or be advised to isolate independently in another place. In the statutory regulations, hospitals have duties and functions that must be carried out and carried out with full responsibility, namely the maintenance and improvement of individual health through complete second and third level health services according to medical needs.

So instead of that the hospital must work on the health of the patients so that they can get well again soon. If anyone is infected with Covid 19 medical personnel must be ready to treat and provide counseling about the procedures for immediately recovering from this viral infection, both procedures during hospitalization and isolation in other places. Medical 
personnel or hospital staff must always monitor patients infected with this virus to know the patient's progress and provide information to patients about the viral infection they are experiencing. In the process of treating patients exposed to the corona virus (covid 19), they must comply with the applicable rules in accordance with the health program that has been made. Periodically the hospital must re-examine patients affected by the corona virus infection (covid 19) to find out the healing process for sick patients. Health services for patients affected by this virus do not consider the status of all to have the same rights in the process of treating this case. When this virus first entered Indonesian society, more and more cases of people affected by this virus and some even died because of being exposed to the corona virus (Covid 19).

Hospitals are increasingly overwhelmed in dealing with patients infected with the corona virus (Covid 19) because the medical personnel who handle the corona virus are few and need additional medical personnel. Hospitals are also increasingly being used to treat covid 19 patients so that inpatient rooms that should be used for other diseases are used as wards for covid 19 patients. The more patients who suffer from this virus, the hospital room is full and cannot accept it. patients affected by covid 19. Here the readiness of the government to deal with patients affected by the corona virus is still far from ready because not all of these covid 19 patients who are hospitalized are treated in other places in independent isolation. Every patient affected by the Covid 19 virus has the same right of treatment before the law. The government must have new policies in tackling the spread and care of patients infected with the corona virus (covid 19) so that all public health rights can be maintained and protected.

\section{Conclusion}

The conclusion from the results of this study is that many patients affected by the corona virus (Covid 19) cannot be hospitalized in the hospital. When the hospital is full of Covid 19 patients it is advised to isolate elsewhere independently. Every patient has the same right to care for the corona virus (Covid 19) to be treated in a hospital. This corona virus pandemic in the government health sector is not yet fully prepared, there are still many people who have not got their right to health. The government must be able to issue new policies that can overcome the current conditions so that all people can get their right to health during a pandemic.

\section{References}

[1] World Health Organization, "Pertimbangan-Pertimbangan Untuk Karantina Individu Dalam Konteks Penanggulangan Penyakit Coronavirus (COVID-19)," no. 2005, pp. 13, 2020, [Online]. Available: https://www.who.int/docs/defaultsource/searo/indonesia/covid19/who-2019-covid19-ihr-quarantine-2020indonesian.pdf?sfvrsn $=31 \mathrm{~d} 7 \mathrm{cbd} 8 \_2$.

[2] Republik Indonesia, "Keputusan Presiden (Keppres) Nomor 11 Tahun 2020 tentang Penetapan Kedaruratan Kesehatan Masyarakat Covid-19.," Pemerintah Indones., no. 031003, pp. 1-2, 2020.

[3] Pemerintah Pusat, "Uu Ri No 4 Tahun 1984," 1984.

[4] Peraturan Pemerintah Nomor 40 Tahun 1991 Tentang Penanggulangan Wabah Penyakit. 1991. 
[5] Presiden Republik Indonesia, "KEPPRES No. 12 Tahun 2020 tentang Penetapan Bencana Nonalam Penyebaran Corona Virus Disease 2019 (COVID-19) Sebagai Bencana Nasional [JDIH BPK RI]," vol. 2019, p. 2, 2020, [Online]. Available: https://peraturan.bpk.go.id/Home/Details/135718/keppres-no-12-tahun-2020.

[6] A. J. Nathan and A. Scobell, "How China sees America," Foreign Aff., vol. 91, no. 5, p. 1, 2012, doi: 10.1017/CBO9781107415324.004.

[7] "Undang-Undang Republik Indonesia Nomor 36 Tahun 2009 Tentang Kesehatan," 2009. 